\title{
12. Rodents from the Baynunah Formation
}

\author{
Brian Kraatz \\ Western University of Health Sciences, Pomona, California, USA \\ bkraatz@westernu.edu
}

\begin{abstract}
The Baynunah Formation of western Abu Dhabi Emirate includes the only record of late Miocene fossil mammals from the Arabian Peninsula. This study reports on new fossil rodents, recording three species previously unknown from the fauna. The first fossil squirrel from the Baynunah Formation is described here, although the limited material makes a detailed taxonomic assessment difficult. An additional indeterminate dendromurine species is also identified. Additionally, a new genus and species of an exceedingly large fossil gerbil, [gen et sp nov], is described. This species exhibits several primitive traits relative to the co-occurring Abudhabia baynunensis, yet is more derived than closely related (yet older) Ameuromys grandis. [gen et sp nov] most likely represents an intermediate species in the Ameuromys grandis - Abudhabia baynunensis group. The rodent fauna also supports previous biochronological estimates for the Baynunah Formation ( 8 to $6 \mathrm{Ma}$ ). The absence of leporids among the Baynunah
\end{abstract}


micromammals suggests the fauna is older than $7 \mathrm{Ma}$. Lastly, although the Baynunah fauna shows a strong African biogeographic signal overall, the rodents represent a portion of the fauna with significant relationships with Asia.

\section{Running head: Rodents}




\section{Introduction}

Renewed paleontological exploration of the Baynunah Formation of the United Arab Emirates since 2002 has expanded our understanding of the microvertebrate component of this late Miocene fauna. Dry screening at several localities has resulted in the recovery of new rodent (Kraatz et al. 2013), herpetile (Head \& Müller this volume) and fish (Otero this volume) material from new microvertebrate localities, adding to the collections previously described by de Bruijn and Whybrow (1994) and de Bruijn (1999). Though an isolated shrew tooth had been previously reported by these authors, no new non-rodent, small mammal material has been recovered and only rodents are reported here. Study of the new material has already resulted in the description of a new thryonomyid species (Kraatz et al. 2013), which was previously known only from a single tooth (de Bruijn and Whybrow 1994; de Bruijn 1999). We here describe all the new material recovered since 2002, identify an additional three species in the Baynunah Formation, and review all previously collected materials (Table 12.1). This work also allows us to update earlier biostratigraphic, biogeographic, and ecological interpretations of the Baynunah fauna based on the micromammal remains.

Previously, de Bruijn and Whybrow (1994) and de Bruijn (1999) suggested that the rodent fauna indicates a late Turolian age $(9.0-5.5 \mathrm{Ma})$ for the Baynunah Formation, and that assessment has been generally supported by additional work on other aspects of the fauna (Bishop and Hill 1999; Tassy 1999; Bibi et al. 2006). De Bruijn (1999) also suggested that a younger (Ruscinian, $<5.3 \mathrm{Ma}$ ) age could not be excluded. It has become clear that a late Turolian age is a well-supported estimate, and that a younger Ruscinian age is inconsistent with various chronological indicators of the Baynunah fauna. 
The original ecological interpretations based on the micromammal fauna were limited by specimen counts and taphonomic bias related to fluvially deposited fossils (de Bruijn 1999). The fauna did, however, include some open habitat species (e.g., Abudhabia), and several species that indicate thick cover was present around the Baynunah riverine system (e.g., Dendromus and a thryonomyid). The latter assessment was partially based on an isolated cane rat tooth, and recovery of additional material later allowed for the description of a new genus and species, Protohummus dango, showing also that this species constituted a much larger portion of the fauna than previously indicated (Kraatz et al. 2013).

Perhaps the most the striking aspect of the micromammal fauna has been a clear biogeographic signal that demonstrates influence from both African and Asian biogeographic regions. Both de Bruijn and Whybrow (1994) and de Bruijn (1999) discussed these influences with regard to the Baynunah gerbil, Abudhabia, and the zapodid and myocricetodontine, all of which show geographic connections to Asia. This initial connection to Asia was recognized as minor (Flynn and Jacobs 1999), but further study, documented here, has since shown that connection to be more extensive. Kraatz et al. (2013) demonstrated this connection through Protohummus, which represents an early cane rat. One of the close ancestors of Protohummus, Paraulacodus indicus from India, shows that there was an even earlier exchange between the Asian continent and the Arabian Peninsula within this lineage. That study also showed that another closely related ancestor to Protohummus, Paraulacodus johanesi from Ethiopia, is even closer in age and geography to the Baynunah Formation.

Abudhabia remains an important taxon that represents the mixture of both Asian 
and African biogeographic elements. De Bruijn (1999) noted that only one other Abudhabia species was known outside of the Arabian Peninsula. Since that time, however, Abudhabia has become a much more widely recognized lineage (Flynn et al. 2003), with occurrences in Kenya (Winkler 2003; Mein and Pickford 2006), Pakistan (Flynn and Jacobs, 1999), India (Patnaik, 1997), Afghanistan (Sen 1983; Flynn et al. 2003), and China (Qiu, Zheng, and Zhang 2004). While Abudhabia was first described from the Baynunah Formation, subsequent discoveries have shown that this taxon has strong Asian affinities, with a more limited representation in eastern Africa.

[TABLE 12.1 HERE]

\section{Methods}

Thryonomyid cusp nomenclature follows Kraatz et al. (2013). Locality information is listed for each referred specimen below, and more detailed descriptions and discussion of fossil rodent localities can be found in Bibi et al. (this volume). All of the newly described specimens here were either surface collected or recovered from dry screening of Baynunah Formation sediments. Sediment was successively screened through $4 \mathrm{~mm}$, $1.3 \mathrm{~mm}$, and $0.6 \mathrm{~mm}$ sieves, and then sorted separately. Almost all new specimens described here were recovered from the matrix sorted at $1.3 \mathrm{~mm}$. Screening methods are discussed in more detail in Kraatz et al. (2013). The teeth were measured using an eyepiece reticle on a stereoscopic microscope, or digitally from a scale-calibrated SEM image.

[TABLE12.2 HERE] 


\section{Systematic Paleontology}

THRYONOMYIDAE Pocock, 1922

Protohummus Kraatz et al., 2013

Protohummus dango Kraatz et al., 2013

Previously referred material— Loc. SHU 4: AUH 571 (L. M2, Fig. 12.1A). Loc. SHU 2-2: AUH 1362 (L. dP 4 ); AUH 1379 (L. M ${ }^{1}$ or 2 , Fig. 1D); AUH 1373 (L. dP 4 , Fig. 12.1B); AUH 1362 (L. dP 4 ); AUH 1428 (L. M ${ }^{1}$ or $)$; AUH 1380 (L. dP ${ }^{4}$, Fig. 12.1C); AUH 1707 (R. $\mathrm{M}^{1 \text { or } 2}$, Fig. 12.1E); AUH 1708 (R. $\mathrm{M}^{1 \text { or } 2}$, Fig. 12.1F); AUH 1419 (dI 2 ); AUH 1423 (M ${ }^{\mathrm{x}}$, broken); AUH $1368\left(\mathrm{dI}^{2}\right)$; AUH $21431\left(\mathrm{M}^{\mathrm{x}}\right)$; AUH $1427\left(\mathrm{dP}_{4}\right.$ or $\mathrm{M}_{\mathrm{x}}$, broken); AUH 1400 (dI 2$)$; AUH 1369 (L. Mx, broken); AUH $1382\left(\right.$ M $\left.^{\mathrm{x}}\right)$; Loc. RAQ 2-1: AUH 1335 (L.

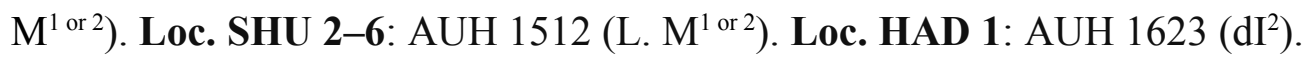
Newly referred material- Loc. SHU 2-2: AUH 1783 (R. M2, Fig. 12.1G); AUH 1786

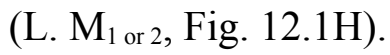

[PLACE FIGURE 12.1 ABOUT HERE; WIDTH = 2 COLUMNS]

\section{Remarks}

AUH $1783\left(\mathrm{M}_{2}\right.$, Fig. 12.1G) and AUH $1786\left(\mathrm{M}^{\text {1or2 }}\right.$ Fig. 12.1H) join previously described material of Protohummus dango (de Bruijn, 1999; Kraatz et al., 2013). Both of these new specimens represent tooth positions already known from this fossil species, and confirm the previously established identification of this taxon. AUH 1783 is most 
similar to the previously described $\mathrm{M}_{2}$ (AUH 571, Fig. 12.1A) based on the lack of curvature and expansion of metalophulid I, which was used to distinguish $\mathrm{M}_{2}$ position from $\mathrm{dP}_{4}$. AUH 1786 is similar to previously described $\mathrm{M}^{1 \text { lor2 }}$. Neither AUH 1783 nor AUH 1786 warrants a revision of the generic or specific diagnoses of Protohummus dango.

MURIDAE Illiger, 1811

GERBILLINAE Gray, 1825

TATERILLINI Chaline et al., 1977

Abudhabia de Bruijn and Whybrow, 1994

Abudhabia baynunensis de Bruijn and Whybrow, 1994

Previously referred specimens-Loc. SHU 1: AUH $572\left(\mathrm{M}^{1}\right)$; AUH $574\left(\mathrm{M}^{2}\right)$; AUH $576\left(\mathrm{M}^{2}\right.$, holotype); AUH $591\left(\mathrm{M}^{1}\right)$; AUH $592\left(\mathrm{M}^{2}\right)$; AUH $593\left(\mathrm{M}^{2}\right)$; AUH $594\left(\mathrm{M}^{2}\right)$; AUH $595\left(\mathrm{M}^{3}\right)$; AUH $596\left(? \mathrm{M}^{3}\right)$; AUH $779\left(\mathrm{M}^{3}\right)$; AUH $597\left(\mathrm{M}_{1}\right)$; AUH $598\left(\mathrm{M}_{1}\right)$; AUH $599\left(\mathrm{M}_{1}\right.$, broken); AUH $568\left(\mathrm{M}_{2}\right)$; AUH $600\left(\mathrm{M}_{2}\right)$; AUH $755\left(\mathrm{M}_{2}\right.$, broken); AUH 756 $\left(\mathrm{M}_{2}\right)$; AUH $765\left(\mathrm{M}_{2}\right.$, broken); AUH $569\left(\mathrm{M}_{3}\right)$; AUH $570\left(\mathrm{M}_{3}\right)$; AUH $766\left(\mathrm{M}_{3}\right)$; AUH 767 $\left(\mathrm{M}_{3}\right)$; AUH $775\left(\mathrm{M}_{3}\right)$. Loc. SHU 4: AUH 573 (M $\mathrm{M}^{1}$, broken); AUH $566\left(\mathrm{M}_{1}\right)$; AUH 567 $\left(\mathrm{M}_{1}\right)$; AUH $781\left(\mathrm{M}_{1}\right.$, broken); AUH $782\left(\mathrm{M}_{2}\right)$; AUH $783\left(\mathrm{M}_{3}\right)$. Loc. MIM 1: AUH 575 $\left(\mathrm{M}^{3}\right)$. 
Newly referred specimens-Loc. SHU 2-2: AUH 1372 (M'1 , broken); AUH $1374\left(\mathrm{M}_{2}\right)$; AUH 1376 (partial left dentary w/M ${ }^{1,}$ Fig. 12.2A and B); AUH 1377 (M²); AUH 1422 $\left(\mathrm{M}_{2}\right)$; AUH $1432\left(\mathrm{M}^{1}\right) ; 1703\left(\mathrm{M}_{1}\right)$; AUH $1704\left(\mathrm{M}^{1}\right)$; AUH $1705\left(\mathrm{M}^{1}\right)$; AUH $1735\left(\mathrm{M}_{1}\right)$. Loc. RAQ 2-1: AUH $1334\left(\mathrm{M}^{2}\right)$; AUH $1341\left(\mathrm{M}^{1}\right)$. Loc. SHU 2-6: AUH $1513\left(\mathrm{M}^{1}\right.$, Fig. 12.2D); AUH 1515 ( $\mathrm{M}^{2}$, Fig. 12.2E); AUH 1516 ( $\mathrm{M}^{1}$, broken); AUH 1521 ( $\mathrm{M}_{1}$, Fig. 12.2C); AUH $1522\left(\mathrm{M}^{2}\right)$.

\section{Remarks}

Though we recovered additional fossil material of Abudhabia baynunensis, abundant previous finds of this taxon from the Baynunah fauna had already revealed its complete dentition. We did recover a partial right dentary with $\mathrm{M}_{1}$ (AUH 1376; Fig. 12.2A \& B), which is the first known non-dental material for this species. AUH 1376 retains the dorsal portion of the alveolus for the missing incisor, but its ventral side has been broken. The dorsal side seems to be complete, which allows for a diastema measurement of $3.92 \mathrm{~mm}$. This is smaller than reported for A. radinskyi (Flynn et al. 2003), but proportional to what would be expected given that the overall all size of A. baynunensis is smaller than $A$. radinskyi. A small foramen is present on the medial proximal portion of the diastema. The first lower molar is complete, and in good condition (Fig. 12.2). Both the posterior and anterior roots of the $\mathrm{M}^{1}$ can be partially observed, and the posterior root is larger than the anterior root. The anterior portion of the alveolus for the second molar is still present; the remainder of the alveolus is gone. Much of lateral ramus is broken away under $\mathrm{M}^{1}$, and there is no remnant of the masseteric fossa. 


\section{[PLACE FIGURE 12.2 ABOUT HERE; WIDTH = 2 COLUMNS]}

Although this is the first non-dental material reported for A. baynunensis, the incomplete nature of this specimen coupled with the paucity of similar material for other closely related species makes systematic and functional interpretations difficult. Overall, Abudhabia species and other closely related taxa are almost solely known from isolated teeth (Flynn et al. 2003). Flynn and Jacobs (1999) describe material of A. pakistanensis that includes a partial maxilla, and Flynn et al. (2003) describe remarkably complete cranial, dental, and skeletal material of $A$. radinskyi that includes multiple dentaries.

On a final note, in reviewing previous collections and reports, AUH 573 is clearly broken and there should not be a length measurement associated with this specimen. De Bruijn (1999, Fig 15.2) illustrated a complete $\mathrm{M}^{1}$ and labeled it as AUH 573, however, that specimen and its measurements in fact belong to AUH 591. De Bruijn and Whybrow (1994) correctly labeled and figured AUH 573.

[gen nov], new genus

Genus diagnosis - As for the new and only species, below

Etymology - Taken from the Arabic word for a hill or mountain, jebel (جبل), which refers to the strong isolation of the anterior cusps, a primitive condition among fossil gerbils, and in honor of Andrew Hill.

[gen et sp nov], new species 
Etymology_Latin for 'king', which refers to the large size of this gerbil, and, combined with the generic name, identifies this species as 'King of the Hill'

Holotype-AUH 1750 (right dentary with $\mathrm{I}$ and $\mathrm{M}_{1-2}$, Fig. 12.3). This is the only specimen known.

Type Locality_-Ruwais South East (RUW SE)

Stratigraphic Range - Currently known only from the late Miocene Baynunah Formation of the United Arab Emirates.

[PLACE FIGURE 12.3 ABOUT HERE; WIDTH = 2 COLUMNS]

Diagnosis - [gen et sp nov] is the largest known fossil gerbil. It is distinguished from Abudhabia spp. by the strong isolated, bunodont cusps on the lower first molar, and the presence of ectostylids on both the first and second lower molars. The cuspate arrangement differs from most other fossil gerbils, which show a derived, lophate pattern. In contrast to other cuspate fossil gerbillids, such as Ameuromys grandis and various myocricetodontines, [gen et sp nov] does not show the presence of any longitudinal crests connecting lophs within molars. Overall, Ameuromys grandis maintains more isolated cusps than [gen et sp nov].

\section{Description}


AUH 1750 is a right lower jaw containing $\mathrm{I}_{2}, \mathrm{M}_{1}$, and $\mathrm{M}_{2}$ (Fig. 12.3). Although some dentary bone remains, most features are not clear. $\mathrm{I}_{2}$ is fractured distally, including the loss of the occlusal surface. Both $\mathrm{M}_{1}$ and $\mathrm{M}_{2}$ are complete and in good condition, showing a moderate stage of wear. There exists a partial alveolus for $\mathrm{M}_{3}$. In general, cusps and ridges of the molars show some exposed dentine through a worn enamel crown. The lower molar teeth of AUH 1750 are bunodont, including inflated cusps and lophs. The anteroconid of $\mathrm{M}_{1}$ is isolated from the metaconid and protoconid, and shows a strong anterior cingulum that projects latero-distally. The $\mathrm{M}_{1}$ also shows a strong metaconid and protoconid that are isolated from one another. These two cusps are arranged obliquely from the long axis of the tooth, which is similar for all cusp pairs and lophs in both molar teeth. The metaconid and anteroconid are approximately equal in size, whereas the protoconid is slightly larger than those two cusps. Distal to the protoconid is a clear, isolated, yet small ectostylid. The entoconid is similar in size to the protoconid. The hypoconid is more irregularly shaped, with a strong posterior cingulum that projects medially.

In contrast to the $\mathrm{M}_{1}$, the $\mathrm{M}_{2}$ exhibits a pair of obliquely arranged lophs. Though not clear, it is likely that isolated cusps have been worn to such a degree that lophs have formed on $\mathrm{M}_{2}$. The metaconid-protoconid loph is stronger on the buccal (protoconid) side. A small, but distinct anterior cingulum projects laterally from the protoconid. The entoconid-hypoconid loph is narrower, and shows a clear posterior cingulum that projects medially from the hypoconid. Given the presence of the anterior cingulum, the tooth is notably longer on its buccal side than on its lingual side. An ectostylid appears 
immediately distal to the protoconid in $\mathrm{M}_{2}$, though this is significantly smaller than the corresponding cusp of $\mathrm{M}_{1}$.

\section{Discussion}

[gen et sp nov] is most remarkably distinct from all other gerbils by its immense size. In comparison, two of the largest fossil gerbils previously described, Myocricetodon magnus $\left(\mathrm{M}_{1}=2.49 \times 1.72 \mathrm{~mm}\right.$, Jaeger 1977) and Ameuromys grandis $\left(\mathrm{M}_{1}{ }_{x}=2.51 \mathrm{x}\right.$ $1.68 \mathrm{~mm}$, Mein and Pickford, 2010) are approximately 50\% smaller in $\mathrm{M}_{1}$ area (30\% smaller in $\mathrm{M}_{1}$ length) than [gen et sp nov] $\left(\mathrm{M}_{1}=3.52 \times 2.4 \mathrm{~mm}\right)$. [gen et sp nov]

compares better to the size of Abudhabia radinskyi $\left(\mathrm{M}_{1}\right.$ length ${ }_{x}{ }^{-}=3.04 \mathrm{~mm}$, Flynn et al. 2003) but remains larger. In addition to significant size differences, [gen et sp nov] also exhibits a unique suite of dental features that further distinguish it from closely related taxa. In general, however, the morphological characteristics of [gen et sp nov] suggest it lies near the suspected emergence of gerbillines from their myocricetodontine ancestors (Jaeger 1977; Chaline et al. 1977). Abudhabia has been a central taxon in understanding the relationship between myocricetodontines and modern gerbils (de Bruijn 1999), and indeed, [gen et sp nov] shares important features with this genus, including the presence of a posterior cingulum on $\mathrm{M}_{1}$ and $\mathrm{M}_{2}$ and the presence of an anterior cingulum on $\mathrm{M}_{2}(\mathrm{de}$ Bruijn 1999). [gen et sp nov] also shows a strong ectostylid on $\mathrm{M}_{1}$, and a clear but more limited ectostylid on $\mathrm{M}_{2}$. No Abudhabia species show such accessory cusps (Flynn and Jacobs 2003). Though some Abudhabia species maintain a very minor presence of a longitudinal crest, this feature is typically found on the upper dentition, which cannot be compared in the present sample. 
In addition to the presence of ectostylids, [gen et sp nov] is distinguished from Abudhabia baynunensis by the presence of more basally inflated cusps, and significantly greater independence of the anterior cusps of $\mathrm{M}_{1}$ - suggesting that even with advanced wear, the tooth would remain more cuspate than lophate (see de Bruijn and Whybrow 1994 for comparison). A. pakistanensis (Flynn and Jacobs 1999) has been described as the most primitive species of Abudhabia (Flynn et al. 2003) based on crown height and stronger anterior cingulum on $\mathrm{M}^{2}$; however, there are no lower teeth known from this species that is easily distinguished from [gen et sp nov] based on size. A. radinskyi is a large fossil gerbil, yet it shows more lophate structures within $\mathrm{M}_{1}$ as compared to [gen et sp nov], no post- or precingulid on $\mathrm{M}_{2}$, and no ectostylids on any lower molar. Other Abudhabia species are distinguished from [gen et sp nov] by exhibiting more derived features overall, which includes more lophate lower molars, and a reduction in the postand precingulum structures on the lower teeth.

[gen et sp nov] shows derived features relative to Myocricetodon magnus, including the presence of a posterior cingulum on $\mathrm{M}_{1}$, a lack of longitudinal crests on lower molars, and the presence of a clear, lateral cingulum extending from the anteroconid of $\mathrm{M}_{1}$ (Jaeger 1977). [gen et sp nov] compares well to the recently described Ameuromys grandis, which Mein and Pickford (2010) suggest might be a direct ancestor of Abudhabia baynunensis. Am. grandis exhibits strong, independent cusps on $\mathrm{M}_{1}$, the presence of posterior cusps on $\mathrm{M}_{1}$ and $\mathrm{M}_{2}$ (posteroconid of Mein and Pickford [2010]; postcingulum here), and an anterior cingulum on $\mathrm{M}_{2}$. One distinct difference, however, is that the anterior cusps of the $\mathrm{M}_{1}$ of Am. grandis show longitudinal connections between anterior lophs as seen in various mycricetodontine species, and which are absent in [gen 
et sp nov]. The posterior cusps (postcingulum) of the lower molars of Ameuromys grandis differ from those of [gen et sp nov] in that they maintain independence and do not merge as distinct postcingulum extensions of the hypoconids as in [gen et sp nov]. Though the ancestry of gerbillines from within myocricetodontines has been largely accepted (Tong 1989; Flynn et al. 2003; Mein and Pickford 2010), there remain critical issues with regard to establishing the monophyly of myocricetodontines and the relationship between basal gerbils such as Abudhabia to crown taterillines (Flynn et al. 2003).

While it is clear that AUH 1750 represents a previously unknown taxon, understanding its generic placement is difficult given the lack of an $\mathrm{M}_{3}$ or upper dentition material from the Baynunah Formation. Agustí and Casanovas-Vila (2003), among others, point out that characters outside the first two lower molars can be important in distinguishing genera and species of gerbils (e.g. Protatera from Abudhabia). In many ways, [gen et sp nov] seems to be an intermediary between the older Ameuromys grandis and the coeval Abudhabia baynunensis, the latter of which is considered to be among the most 'primitive' Abudhabia species (Flynn et al. 2003). The anterior cusps of [gen et $s p$ nov] resemble those of A. baynunensis, but they maintain a more distinctly independent arrangement that suggests a more primitive condition. The independence of these cusps is more similar to Ameuromys grandis, which has an even more primitive condition in which the posterior cusps of $\mathrm{M}_{1}$ maintain greater independence. Placing this new species in either Abudhabia or Ameuromys is problematic, as it does not more clearly align into either genus; however the close relationship to both genera is clear. I have chosen to 
create a new genus to reflect the likely scenario that [gen et sp nov] represents a transitional taxon along a paraphyletic Ameuromys-Abudhabia lineage.

MURINAE Gray, 1821

Parapelomys Jacobs, 1978

Parapelomys cf. charkhensis, Brandy, 1979

Previously referred specimens-Loc. SHU 1: AUH $776\left(\mathrm{M}^{1}\right)$; AUH $757\left(\mathrm{M}^{2}\right)$; AUH $579\left(\mathrm{M}_{2}\right)$; AUH $758\left(\mathrm{M}_{2}\right)$; AUH $580\left(\mathrm{M}_{3}\right)$; AUH $777\left(\mathrm{M}_{3}\right)$. Loc. MIM 1: AUH $581\left(\mathrm{M}^{2}\right)$; AUH $582\left(\mathrm{M}^{2}\right)$. Loc. SHU 4: AUH $583\left(\mathrm{M}^{2}\right)$.

Newly referred specimens-Loc. RAQ 2-1: AUH $1347\left(\mathrm{M}_{2}\right)$. Loc. SHU 2-6: AUH $1514\left(\mathrm{M}_{2}\right.$, Fig. 12.4A).

\section{Remarks}

Both new specimens are referred to Parapelomys cf. charkhensis due to similarity to material previously described by de Bruijn and Whybrow (1994) and de Bruijn (1999). The placement of all these specimens within Parapelomys is still a matter of question. De Bruijn and Whybrow (1994) reported that AUH 581 was damaged, and therefore unmeasurable. In a later study, de Bruijn (1999) reported that AUH 582 was too broken to be measured. Both publications report the same measurement for AUH 581 and AUH 582 , respectively, while reporting the other tooth as broken. Review of these specimens 
shows that AUH 581 is broken, while AUH 582 is not, and the measurements reported by de Bruijn and Whybrow (1994) and de Bruijn, (1999) are valid for AUH 582.

[PLACE FIGURE 12.4 ABOUT HERE; WIDTH = 2 COLUMNS]

\section{MYOCRICETODONTINAE Lavocat, 1961}

Myocricetodon Lavocat, 1952

Myocricetodon sp. nov.

Myocricetodon sp. nov. in de Bruijn, 1999

Previously referred specimens_Loc. SHU 1: AUH $773\left(\mathrm{M}^{1}\right)$; AUH $778\left(\mathrm{M}^{1}\right)$; AUH $763\left(\mathrm{M}_{2}\right)$; AUH $780\left(\mathrm{M}_{2}\right)$. Loc. MIM 1: AUH $589\left(\mathrm{M}^{1}\right)$.

Remarks-We recovered no new material of the Myocricetodon sp. nov., which was previously described by de Bruijn and Whybrow (1994) and de Bruijn (1999), and no revisions are given here. Previous discussions suggest that this new species is similar to M. parvus in size and similar to both $M$. trerki and M. ouedi in the expression of the posterior cingulum. As we did not find additional material of this taxon, we defer to de Bruijn and Whyrow's (1994) and de Bruijn's (1999) previous assessment that this material is currently too limited to serve as the basis for a new name.

DENDROMURINAE Alson, 1876 


\section{Dendromurinae gen. et sp. indet. 1}

Dendromus aff. melanotus in de Bruijn, 1999

Dendromus sp. 1 in de Bruijn and Whybrow, 1994

Previously referred specimens_Loc. SHU 1: AUH $584\left(\mathrm{M}^{1}\right)$; AUH $587\left(\mathrm{M}^{1}\right)$; AUH

$759\left(\mathrm{M}^{2}\right)$; AUH $760\left(\mathrm{M}_{1}\right)$; AUH $585\left(\mathrm{M}_{2}\right)$; AUH $588\left(\mathrm{M}_{2}\right)$; AUH $761\left(\mathrm{M}_{2}\right)$.

Remarks - We recovered no new material of the dendromurine previously described by de Bruijn (1999) as Dendromus aff. melanotus and de Bruijn and Whybrow (1994) as Dendromus sp. 1. This material is only questionably referable to Dendromus, and therefore we have revised its placement until additional comparative study can be concluded.

\section{Dendromurinae gen. et sp. indet. 2}

Newly referred specimens - Loc. SHU 2-2: AUH 1436 (Mํ, Fig. 12.4B)

Remarks - We recovered one upper first molar (AUH 1436), which represents a lightly worn tooth, and compares well to other dendromurines in the Baynunah fauna. The tooth has several distinct differences to the other dendromurine material, however, including more transverse and bunodont cusps. It also shows an enlarged lingual entocone that spans both the paracone-protocone and metacone-hypocone lophs, as compared to the 
smaller and more mesialy positioned entocone of Dendromurinae sp. indet. 1. This specimen appears distinct from other dendromurine material in the fauna, permitting the identification of a third dendromurine species, though there is inadequate detail to allow for a more specific identification.

Dendromus, Smith, 1828

Dendromus sp.

Dendromus sp. 2 in de Bruijn and Whybrow, 1994

Dendromus sp. in de Bruijn, 1999

Previously referred specimens-Loc. SHU 1: AUH $586\left(\mathrm{M}^{2}\right)$; AUH $762\left(\mathrm{M}_{2}\right)$; AUH $772\left(\mathrm{M}_{2}\right)$

Remarks - We recovered no new material of the larger dendromurine, which was previously described by de Bruijn and Whybrow (1994) as Dendromus sp. 2 and Dendromus sp. by de Bruijn, 1999. The dendromurinae of the Baynunah fauna warrant more detailed study, a task made difficult by the limited material.

\section{DIPODIDAE}

Zapodinae gen. et. sp. indet.

Previously referred material-Loc. SHU1: AUH $774\left(\mathrm{M}_{1}\right)$. 
Remarks-We recovered no new material of the zapodine previously described by de Bruijn (1999), and no revisions are given here.

SCIURIDAE Fischer de Waldheim, 1817

gen. and sp. indet.

Newly referred material—Loc. SHU 2-2: AUH 1378 (L M ${ }^{1}$ or 2 , Fig. 12.5A); AUH 1706 (Left $\mathrm{M}_{1 \text { or } 2}$, Fig. 12.5B).

\section{Description}

Although AUH 1378 and AUH 1706 were found at different localities, the similarity in overall morphology and relatively large size (considering tooth position) suggests that they are likely from the same taxon. AUH 1378 is an upper left first or second molar showing moderate wear. All primary cusps show exposed dentine. Overall the enamel is smooth, and while there are lophate structures present, the lophs are not so strong as to create deep basins. The tooth shows a strong anteroloph and associated anterior basin that equals about one quarter the overall length of the tooth. The anteroloph includes a clear anteroconule and parastyle. The parastyle is aligned buccally to the paracone, whereas the anteroconule does not extend lingually as far as the protocone. The protocone is the dominant cusp of the tooth, and the paracone, hypocone, and metaconule are of roughly equal size. The hypocone and metacone are slightly shifted lingually relative to the protocone and paracone, respectively. The metacone is smaller than the metaconule, and both are connected by a clear metaloph, that does not connect lingually with the 
hypocone. There is a minor but clear mesostyle equidistant between the paracone and metacone. The tooth also shows a strong posteroloph that begins buccally just lingual to the metacone, and extends nearly to the hypocone, but does not connect with that structure. The tooth has three roots, a single (strongest) lingual root, and two buccal roots. One of the buccal roots is completely broken, but the base of the other remains. The lingual root is more complete, and projects straight down from the crown, showing no curvature in the bucco-lingual or mesio-distal plane.

AUH 1706 is a lower left first or second molar showing a moderate level of wear, similar to AUH 1378. The lingual mesiodistal length is shorter than on the buccal side. The enamel texture and relative depth of the trigonid basin is similar to the condition in AUH 1378. The protoconid and hypoconid are the strongest cusps on the tooth, and each is connected to an adjacent smaller cusp. The protoconid is connected directly to an anteroconulid, but that loph does not extend more lingually beyond that cusp. A minor loph connects the protoconid and hypoconid, but there is no evidence of any expansion that might indicate the presence of a mesoconid on that structure. At the midpoint of this loph, a small sinusid extends toward the base of the crown. The hypoconulid is strongly connected to the hypoconid. Dentine is exposed along the loph between these two cusps, and while an enamel ridge does extend lingually from the hypoconulid to the entoconid (i.e., posterolophid), no dentine is exposed in that area. The entoconid is located along the lingual edge of the tooth, and extends beyond the position of the metaconid. Though a minor loph-like structure extends buccodistally from the entoconid anterior to the posterolophid, the structure is likely a wear facet. There is no mesostylid present between the entoconid and metaconid. The metaconid is aligned just distal to the anteroconulid 
and mesial to the protoconid. The tooth shows four equally sized roots, of which only the bases remain.

Sciurids are previously unreported from the Baynunah fauna. The sciurid affinities of specimens AUH 1378 and 1706 are clear, but determining placement among the diverse lineages of this family is more problematic. Overall, the morphology of the large Baynunah sciurid is low crowned and more brachydont than many other fossil sciurids, and cusp arrangement indicates a more simplified, tribosphenic condition.

\section{Discussion}

Our work has significantly expanded the micromammal fossil record of the Baynunah Formation by increasing the abundance of previously known taxa, describing new taxa previously unknown to the Baynunah fauna, and expanding the geographic area from which microfossils have been recovered within the Baynunah Formation. In addition to the previously described cane rat (Protohummus dango, Kraatz et al. 2013), I here add three taxa to the Baynunah fauna: a new large species of fossil gerbil ([gen et sp nov]), an indeterminate dendromurine, and a fossil sciurid. Because of the limited amount of material associated with our sciurid, its systematic placement is difficult, and in turn, ecological interpretations are not possible.

The new Baynunah gerbil, [gen et sp nov], indicates several interesting aspects with regard to gerbil evolution and the paleobiogeographic implications of the Baynunah fauna. Morphologically, it seems to be an intermediary within an Ameuromys grandis Abudhabia baynunensis lineage, which makes the co-occurrence of this taxon with $A$. baynunensis surprising. Ameuromys grandis is known from sediments in Egypt that date 
to ca. $11 \mathrm{Ma}$ (Mein and Pickford 2010), leaving a large temporal gap between those deposits and the Baynunah Formation, which is best estimated to be between $8 \mathrm{Ma}$ and 6 Ma (Whybrow and Hill 1999; Bibi et al. 2013; Peppe et al. this volume). Given the morphological placement of [gen et sp nov], it would be expected that this taxon would not appear concurrently with Abudhabia baynunensis, but this does not suggest that a revision of the age of the Baynunah fossil record is necessary. A more likely scenario is that [gen et sp nov] is a late-surviving intermediary lineage, and that it might be expected to occur elsewhere on the Arabian Peninsula or northern Africa in slightly older sediments. Abudhabia remains a distinct indictor that there are strong Asian connections to the Baynunah fauna, but if [gen et sp nov] is indeed an intermediary between Ameuromys grandis and Abudhabia baynunensis, the root of that lineage could lie in northern Africa and/or the Arabian Peninsula. The substantial material of Protohummus dango further suggests that there was persistent covered habitat nearby the Baynunah River.

Screen washing of the Baynunah Formation for microvertebrates has now occurred over the course of several decades (de Bruijn and Whybrow 1994; de Bruijn 1999; Kraatz et al. 2013; Otero this volume; Head and Müller this volume). Given our expansive understanding of the Baynunah fauna overall, and a greatly increased understanding of the micromammal fauna, it is appropriate to discuss biological reasons why some expected taxa may be missing from the Baynunah fauna. This is particularly relevant with regard to the micromammal assemblage; despite significant field efforts and substantial finds, the Baynunah Formation has never produced a fossil leporid. Though leporids could have been part of this late Miocene fauna and simply not yet have been 
recovered, given the extensive micro-fauna that has been discovered thus far, it is becoming increasingly likely that they were absent from the fauna. This later scenario has biochronological implications related to an important biomarker event, the Leporid Datum (LD), discussed by Flynn et al. (2014). The LD describes the first appearances of leporids in Eurasia and Africa in the late Miocene. The first leporid dispersals from North America into northern Asia occur $\sim 8 \mathrm{Ma}$, reaching South Asia by 7.4 Ma, and Africa by 7.0 Ma. If the absence of leporids in the Baynunah indicates a true ecological absence, it would imply that the age of the Baynunah Formation was $>7 \mathrm{Ma}$, which would further constrain its age to the older part of the current $8 \mathrm{Ma}$ to $6 \mathrm{Ma}$ estimate.

\section{Acknowledgements}

This work was supported by the Abu Dhabi Department of Culture and Tourism (formerly TCA, formerly ADACH), the Abu Dhabi Public Works Department (no longer existing), and the US National Science Foundation (grants OISE-0852975 to Faysal Bibi, Revealing Hominin Origins Initiative 0321893 to T. White and F. C. Howell). I thank Gabriel Santos and Alf Museum for help with photographic imaging of AUH 1750 and Larry Flynn for early discussions on the rodent fauna, and in particular helpful guidance on the large fossil gerbil described herein. I thank the American Museum of Natural History for use of SEM imaging equipment A. Al Kaabi, O. Al Kaabi, A.-R. Al Nuaimi, M. Al Neyadi, A. al Hajj, W. A. Omer, W. Yasin, A. Attar, E. Moacdieh, S. Majzoub, K. Zreik, F. Bibi, M. Beech, A. Hill, and N. Craig are warmly thanked for helping with the arduous task of screening, picking, and finding the micro-mammal fossil specimens. 
Larry Flynn, Alisa Winkler, and another anonymous reviewer provided very helpful reviews of this manuscript, for which I am grateful. Lastly, I thank Andrew Hill for initiating the earliest stages of the greater Baynunah project with Peter Whybrow, and for his immeasurable collegiality. Over my decades of fieldwork throughout the world, with personalities and characters of every variety, working with Andrew in the Baynunah Formation was one of my greatest pleasures. He is missed. Always.

\section{References Cited}

Agustí, J., \& Casanovas-Vilar, I.. (2003). Neogene gerbils from Europe. Deinsea 10, 1322.

Bibi F., Shabel, A. B., Kraatz, B. P., \& Stidham, T. A. (2006). New fossil ratite (Aves: Palaeognathae) eggshell discoveries from the Late Miocene Baynunah Formation of the United Arab Emirates, Arabian Peninsula. Palaeontologia Electronica 9:2A, $13 p$.

Bibi, F., Beech, M., Hill., A, \& Kraatz, B. (this volume). Fossil Localities of the Baynunah Formation. In F. Bibi, B. Kraatz, M. Beech, \& A. Hill (eds.) Sands of Time: Late Miocene Fossils from the Baynunah Formation, U.A.E. (pp. xxx). Cham: Springer.

Bishop, L.C., \& Hill, A. (1999). Fossil Suidae from the Baynunah Formation, Emirate of Abu Dhabi, United Arab Emirates. In P.J. Whybrow \& A. Hill (Eds.), Fossil Vertebrates of Arabia, with Emphasis on the Late Miocene Faunas, Geology, and Palaeoenvironments of the Emirate of Abu Dhabi, United Arab Emirates (pp 254270). Yale University Press, New Haven.

de Bruijn, H., \& Whybrow, P.J. (1994). A Late Miocene rodent fauna from the Baynunah Formation, Emirate of Abu Dhabi, United Arab Emirates. Proceedings of the 
Koninklijke Nederlandse Akademie van Wetenschappen.

Biological, chemical, geological, physical, and medical sciences. 97, 407-422

de Bruijn H. (1999). A late Miocene insectivore and rodent fauna from the Baynunah Formation, Emirate of Abu Dhabi, United Arab Emirates. In P.J. Whybrow \& A. Hill (Eds.), Fossil Vertebrates of Arabia, with Emphasis on the Late Miocene Faunas, Geology, and Palaeoenvironments of the Emirate of Abu Dhabi, United Arab Emirates. (pp 186-200). New Haven: Yale University Press.

Chaline, J., Mein, P., \& Petter, F. (1977). Les grandes lignes d'une classification évolutive des Muroidea. Mammalia, 41, 245-252.

Flynn, L.J., \& Jacobs, L.L. (1999). Late Miocene small-mammal faunal dynamics: the crossroads of the Arabian Peninsula. In P.J. Whybrow \& A. Hill (Eds.), Fossil Vertebrates of Arabia, with Emphasis on the Late Miocene Faunas, Geology, and Palaeoenvironments of the Emirate of Abu Dhabi, United Arab Emirates. (pp 410419). New Haven: Yale University Press.

Flynn, L. J., Winkler, A. J., Jacobs, L. L., \& Downs, W. (2003): Chapter 23: Tedford's Gerbils from Afghanistan. Bulletin of the American Museum of Natural History. 603-624

Flynn, L.J., Winkler, A.J., Erbaeva, M., Alexeeva, N., Anders, U., Angelone, C., et al. (2014). The Leporid Datum: a late Miocene biotic marker. Mammal Review, 44, 164-176.

Head, J. \& Müller, J. (this volume). Amphibians and squamates from the Baynunah Formation. In F. Bibi, B. Kraatz, M. Beech, \& A. Hill (eds.) Sands of Time: Late 
Miocene Fossils from the Baynunah Formation, U.A.E. (pp. xxx). Cham: Springer.

Jaeger, J.J. (1977). Les rongeurs du Miocène moyen et supérieur du Maghreb. Palaeovertebrata, 8, 1-166.

Kraatz, B. P., Bibi, F., Hill, A., \& Beech, M. (2013) A new fossil thryonomyid from the Late Miocene of the United Arab Emirates and the origin of African cane rats. Naturwissenschaften, 100, 437-449.

Mein, P. \& Pickford, M., (2006). Late Miocene micromammals from the Lukeino Formation (6.1 to $5.8 \mathrm{ma})$, Kenya. Publications de la Société Linnéenne de Lyon, 75, 183-223.

Mein, P., \& Pickford, M. (2010) Vallesian rodents from Sheikh Abdallah, Western Desert, Egypt. Historical Biology, 22, 224-259.

Otero, O. (this volume). Fishes from the Baynunah Formation. In F. Bibi, B. Kraatz, M. Beech, \& A. Hill (eds.) Sands of Time: Late Miocene Fossils from the Baynunah Formation, U.A.E. (pp. xxx). Cham: Springer.

Peppe, D. J., Evans, D. A. D., Beech, M., Hill, A., Bibi, F. (this volume). Magnetostratigraphy of the Baynunah Formation. In F. Bibi, B. Kraatz, M. Beech, \& A. Hill (eds.) Sands of Time: Late Miocene Fossils from the Baynunah Formation, U.A.E. (pp. xxx). Cham: Springer.

Patnaik, R. (1997). New murids and gerbillids (Rodentia, Mammalia) from Pliocene Siwalik sediments of India. Palaeovertebrata 26, 129-165.

Qiu,Z., Zheng, S., \& Zhang, Z. (2004) Gerbillids from the Late Miocene Bahe Formation, Lantian, Shaabnxi. Vertebrata Palasiatica, 42, 903-204. 
Sen, S. (1983). Rongeurs et Lagomorphes du gisement Pliocène de Pul-e Charki, bassin de Kabul, Afghanistan. Bulletin du Museum National d'Histoire Naturelle, Paris, $5 C, 33-74$.

Tassy P. (1999). Miocene elephantids (Mammalia) from the Emirate of Abu Dhabi, United Arab Emirates; palaeobiogeographic implications. In P.J. Whybrow \& A. Hill (Eds.), Fossil Vertebrates of Arabia, with Emphasis on the Late Miocene Faunas, Geology, and Palaeoenvironments of the Emirate of Abu Dhabi, United Arab Emirates. (pp 209-233). New Haven: Yale University Press.

Tong, H. (1989). Origine et évolution des Gerbillidae (Mammalia, Rodentia) en Afrique du Nord. Mémoires de la Société Géologique de France, 155, 1-120.

Whybrow, P.J. \& Hill, A. (Eds.) (1999). Fossil Vertebrates of Arabia, with Emphasis on the Late Miocene Faunas, Geology, and Palaeoenvironments of the Emirate of Abu Dhabi, United Arab Emirates. New Haven: Yale University Press. 523 p.

Winkler, A. J. (2003). Rodents and lagomorphs from the Miocene and Pliocene of Lothagam, Northern Kenya. In M.G. Leakey, \& J.M. Harris (Eds), Lothagam: The Dawn of Humanity in Eastern Africa. (pp. 169-190). New York: Columbia University Press.

\section{Figure Captions}

Figure 12.1. SEM images of occlusal views of isolated Protohummus dango teeth from the Baynunah Formation, United Arab Emirates. A = AUH 571 (holotype; L. $\mathrm{M}_{2}$ ); B =

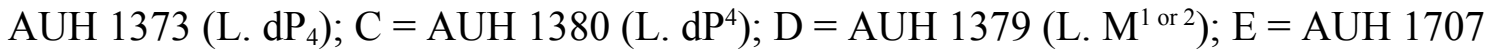


$\left(\mathrm{L} . \mathrm{M}^{1 \text { or } 2}\right) ; \mathrm{F}=\mathrm{AUH} 1708\left(\mathrm{R} . \mathrm{M}^{1 \text { or } 2}\right) ; \mathrm{G}=\mathrm{AUH} 1783\left(\mathrm{R} . \mathrm{M}_{2}\right) ; \mathrm{H}=\mathrm{AUH} 1786\left(\mathrm{~L} . \mathrm{M}^{1 \text { or }}\right.$

${ }^{2}$ ). Horizontal scale bar in $\mathrm{A}=1 \mathrm{~mm}$, which is applicable for all teeth. Teeth are shown in occlusal views with the buccal side towards top.

Fig. 12.2. SEM images of Abudhabia baynunensis from the Baynunah Formation, United Arab Emirates. A (occlusal view) and B (lateral view) = AUH 1376 (partial L. dentary $\left.\mathrm{w} / \mathrm{M}_{1}\right) ; \mathrm{C}=\mathrm{AUH} 1521\left(\mathrm{M}_{1}\right) ; \mathrm{D}=\mathrm{AUH} 1513\left(\mathrm{M}^{1}\right) ; \mathrm{E}=\mathrm{AUH} 1515\left(\mathrm{M}^{2}\right)$. Scale bar in $\mathrm{A}=$ $1 \mathrm{~mm}$ and is applicable for B. Scale bar in $\mathrm{C}=0.5 \mathrm{~mm}$ and is applicable for D and E.

Figure 12.3. Photo images of holotype AUH 1750, a right dentary including $\mathrm{M}_{1}$ of [gen et sp nov], gen. and sp. nov., from the Baynunah Formation, United Arab Emirates. A and B occlusal and C lateral views. Scale bars in A and B are equal to $1 \mathrm{~mm}$ in length, and scale bar in B is applicable for C.

Figure 12.4. SEM images of new fossil rodent material from the Baynunah Formation, United Arab Emirates. Scale bar $=0.5 \mathrm{~mm} . \mathrm{A}=$ Parapelomys $c f$. charkhensis, AUH 1514 $\left(\mathrm{M}_{2}\right) ; \mathrm{B}=$ Dendromurinae indet., AUH $1436\left(\mathrm{M}^{1}\right)$.

Figure 12.5. SEM images of two fossil teeth of a sciurid from the Baynunah Formation, United Arab Emirates. A = AUH $1378\left(\mathrm{~L} . ~^{1}{ }^{1 \text { or } 2}\right)$ and $\mathrm{B}=\mathrm{AUH} 1706\left(\mathrm{~L}>\mathrm{M}_{1 \text { or } 2}\right)$. Scale bar $=0.5 \mathrm{~mm}$. 
Table 12.1 Faunal list of rodent species in the Baynunah Formation.

Thryonomyidae

\section{Protohummus dango}

Muridae

Gerbillinae

Abudhabia baynunensis

[gen et sp nov] gen. and sp. nov.

Murinae

Parapelomys cf. charkhensis,

Myocricetodontinae

Myocricetodon sp. nov.

Nesomyidae

Dendromurinae

Dendromurinae indet. 1

Dendromurine indet. 2

\section{Dendromus sp.}

\section{Dipodidae}

Zapodinae gen. et. sp. indet.

Sciuridae gen. et. sp. indet. 
Table 12.2 Dental measurements (in $\mathrm{mm}$ ) for teeth discussed in text. * denotes measurement unavailable due to broken tooth.

\begin{tabular}{|c|c|c|c|c|c|c|c|c|c|c|c|c|c|c|c|c|c|}
\hline \multirow[t]{2}{*}{ Species } & \multirow[t]{2}{*}{$\begin{array}{l}\text { Speci } \\
\text { men }\end{array}$} & \multicolumn{2}{|c|}{ dP4 } & \multicolumn{2}{|c|}{ M1 } & \multicolumn{2}{|c|}{ M2 } & \multicolumn{2}{|c|}{ M1or2 } & \multicolumn{2}{|c|}{ dp4 } & \multicolumn{2}{|c|}{ m1 } & \multicolumn{2}{|c|}{ m2 } & \multicolumn{2}{|c|}{ m1or2 } \\
\hline & & $\mathbf{L}$ & $\mathbf{W}$ & $\mathbf{L}$ & $\mathbf{W}$ & $\mathbf{L}$ & $\mathbf{W}$ & $\mathbf{L}$ & $\mathbf{W}$ & $\mathbf{L}$ & $\mathbf{W}$ & $\mathbf{L}$ & $\mathbf{W}$ & $\mathbf{L}$ & $\mathbf{W}$ & $\mathbf{L}$ & $\mathbf{W}$ \\
\hline $\begin{array}{l}\text { Abudhabia } \\
\text { bayunensis }\end{array}$ & 1334 & & & & & 1.58 & $\begin{array}{c}1.4 \\
9\end{array}$ & & & & & & & & & & \\
\hline & 1341 & & & 2.59 & 1.76 & & & & & & & & & & & & \\
\hline & 1372 & & & $*$ & $*$ & & & & & & & & & & & & \\
\hline & 1374 & & & & & & & & & & & & & 1.75 & 1.63 & & \\
\hline & 1376 & & & & & & & & & & & 2.21 & 1.41 & & & & \\
\hline & 1377 & & & & & 1.66 & 1.6 & & & & & & & & & & \\
\hline . & 1422 & & & & & & & & & & & & & 1.78 & 1.65 & & \\
\hline & 1432 & & & 2.29 & 1.66 & & & & & & & & & & & & \\
\hline & 1513 & & & 2.61 & 1.73 & & & & & & & & & & & & \\
\hline & 1515 & & & & & 1.56 & $\begin{array}{c}1.5 \\
2\end{array}$ & & & & & & & & & & \\
\hline & 1521 & & & & & & & & & & & 2.43 & 1.57 & & & & \\
\hline
\end{tabular}




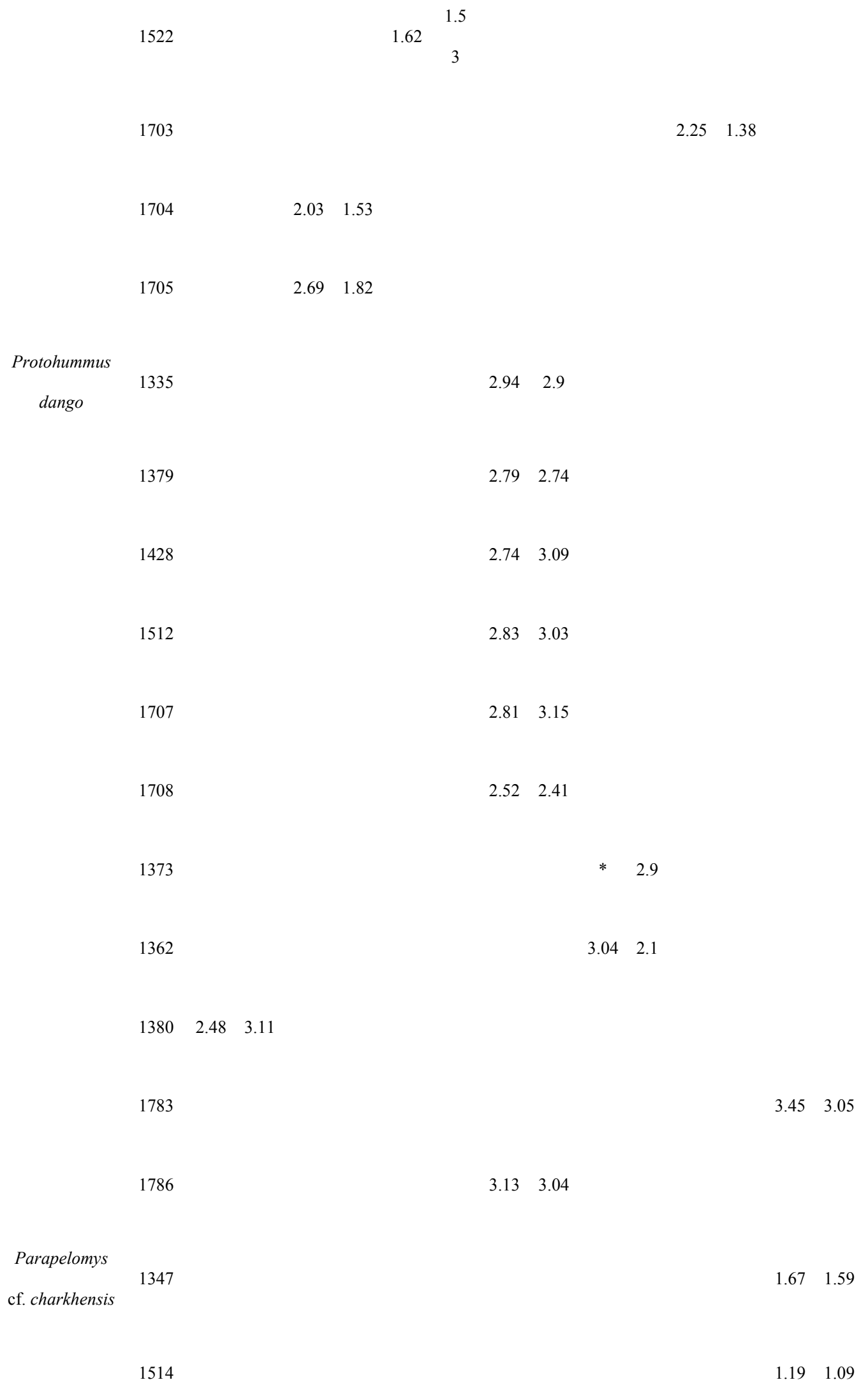




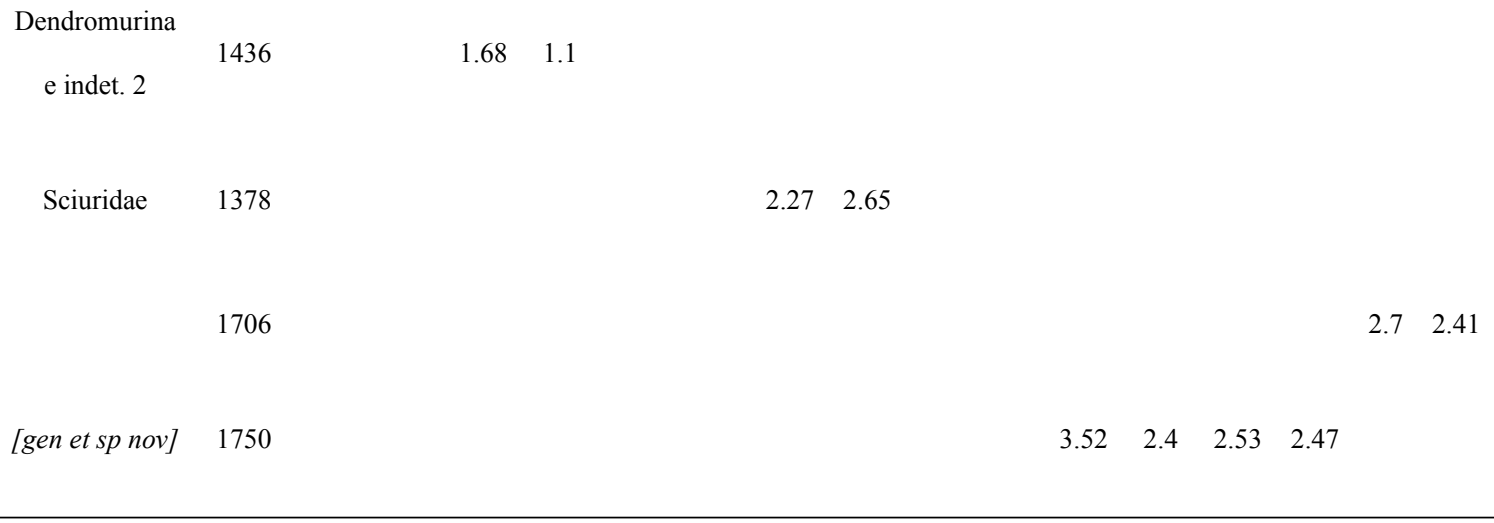


A

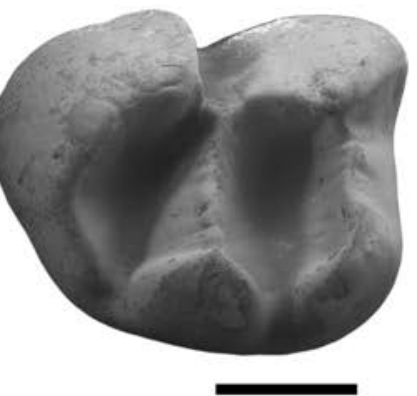

D

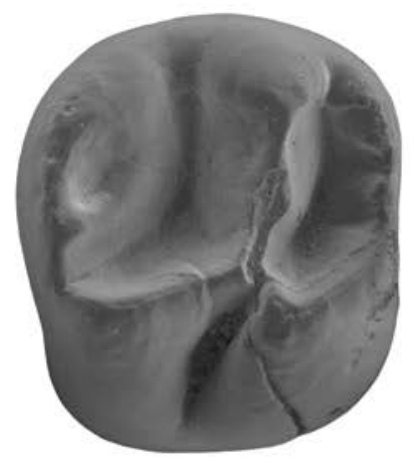

G

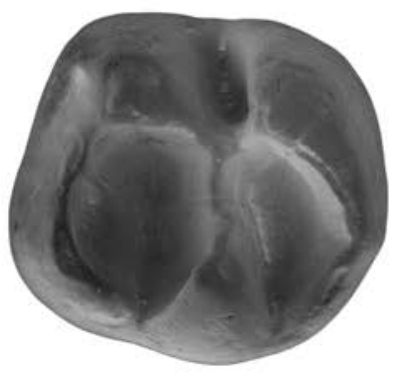

B
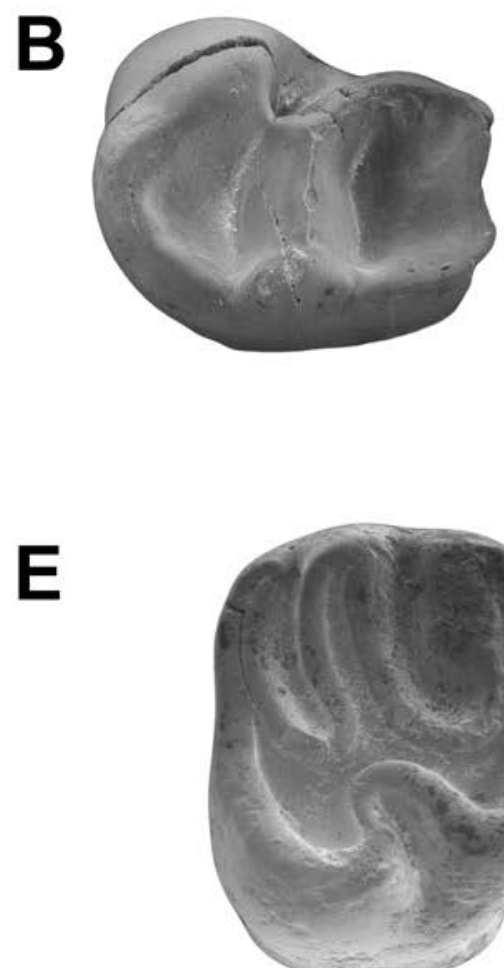

H

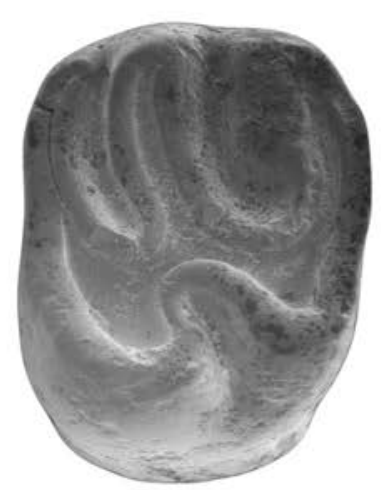

F
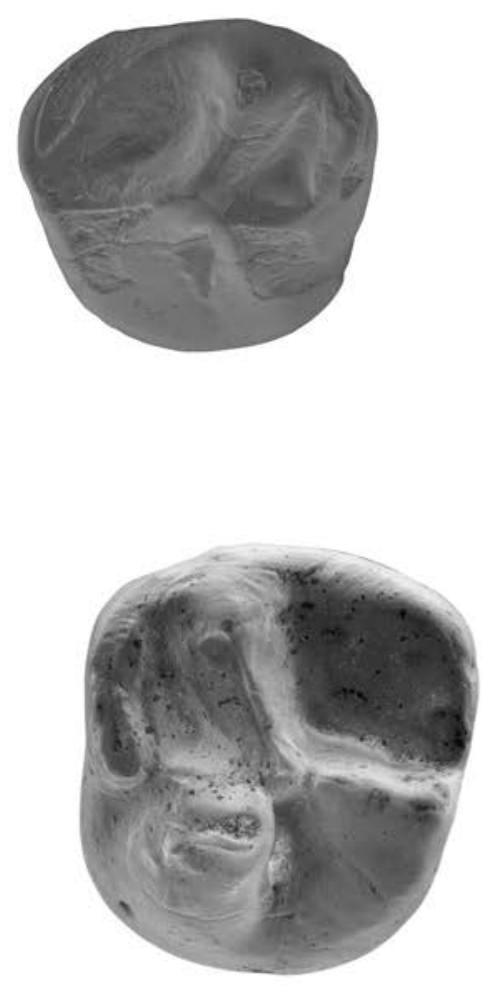

Figure 12.1 
A

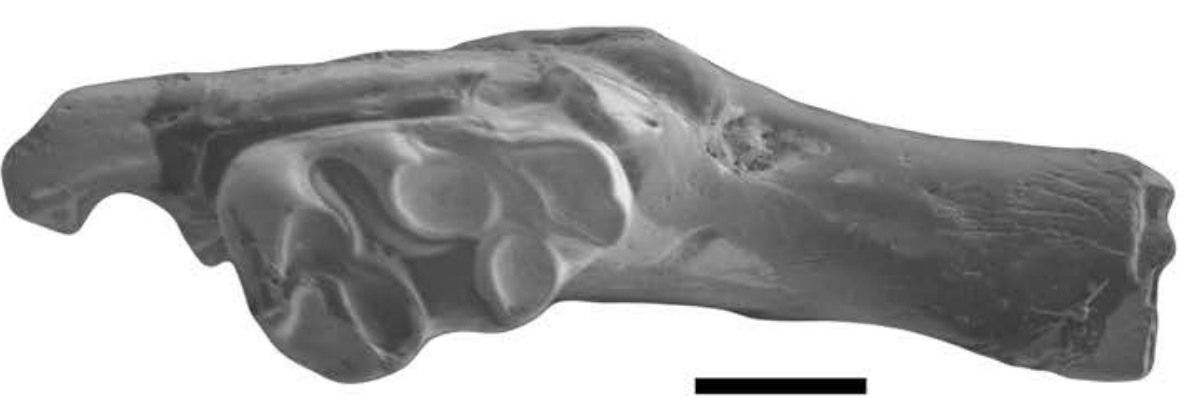

C

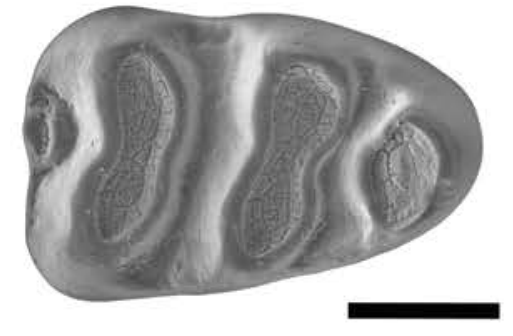

D

B

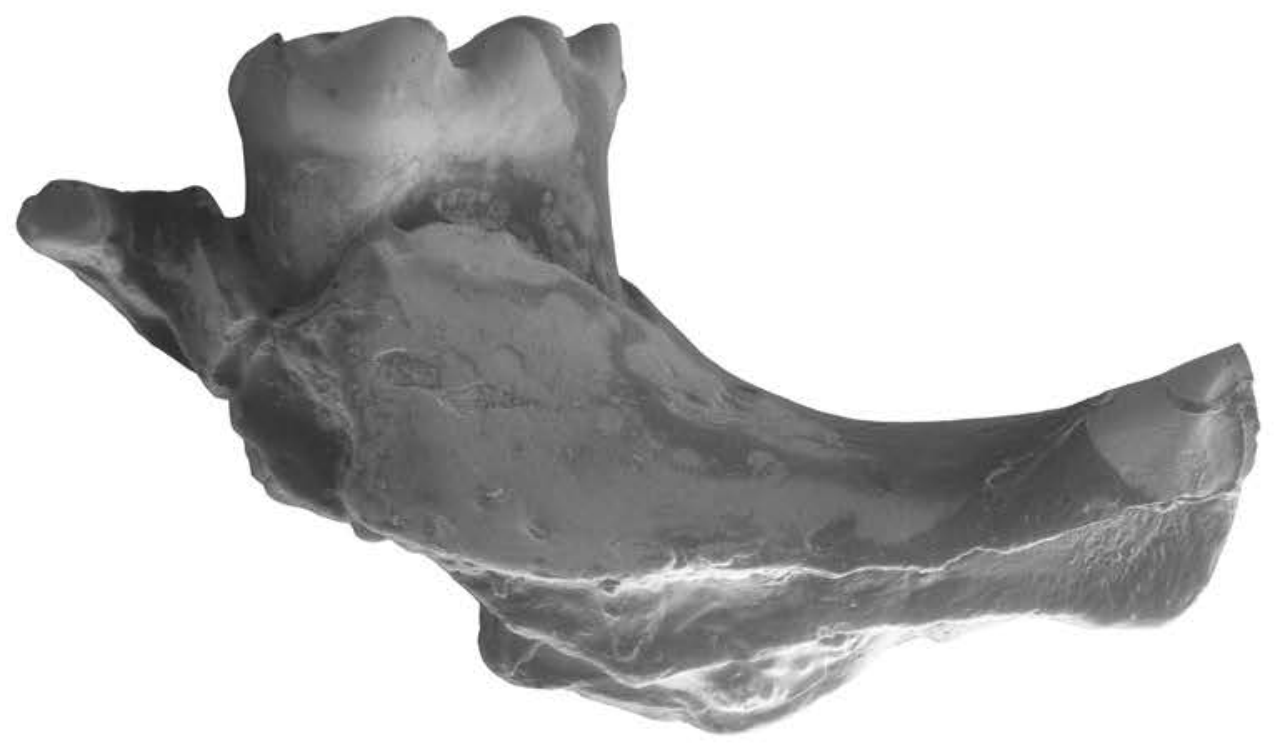

E

Fig. 12.2 

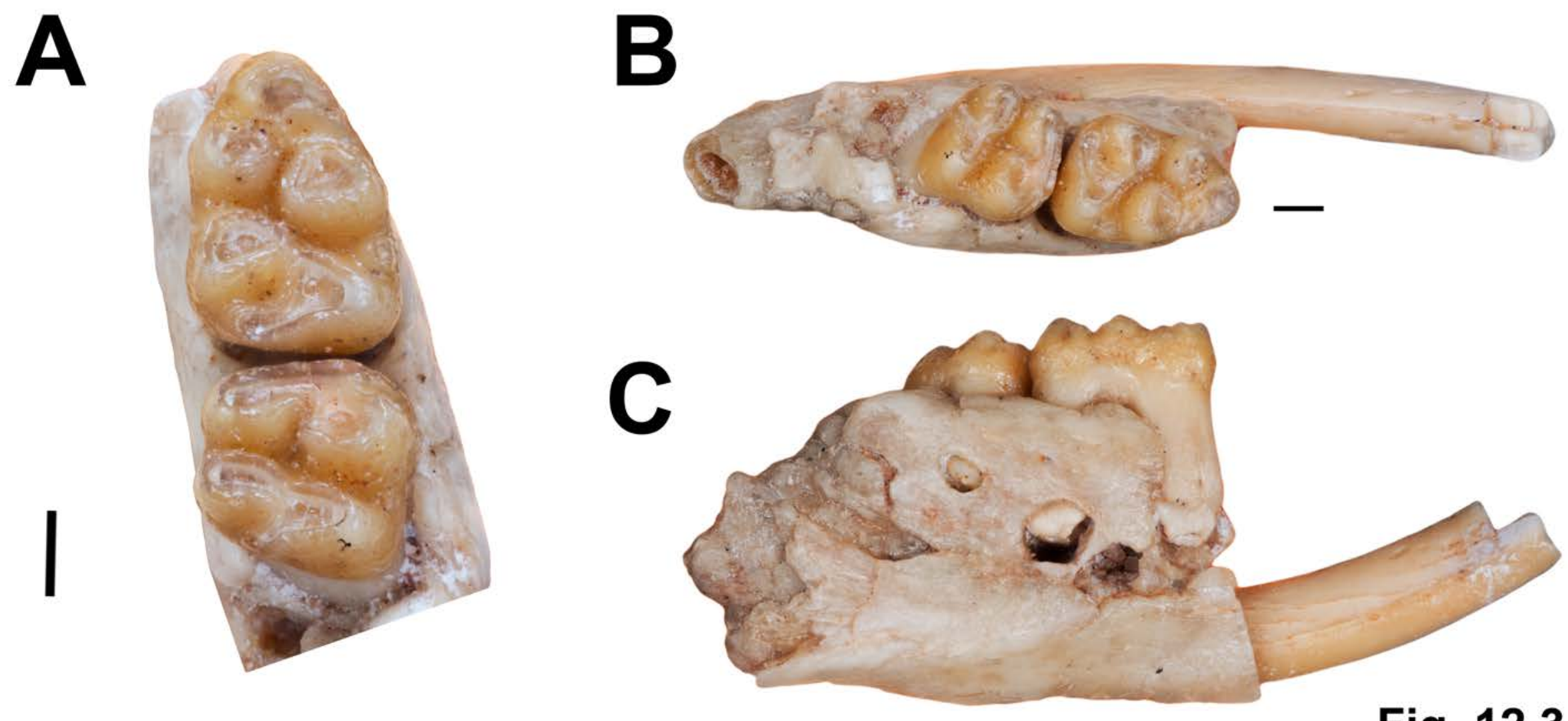

Fig. 12.3 
A

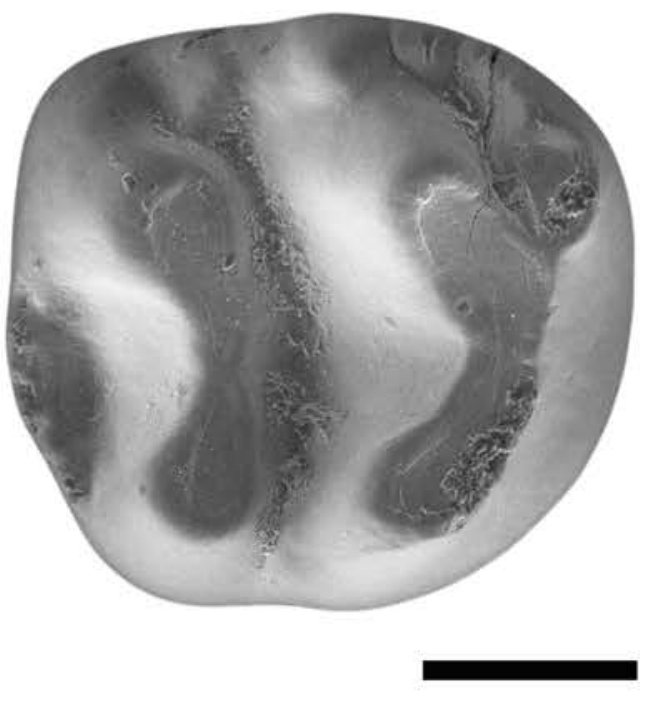

B

Fig. 12.4 


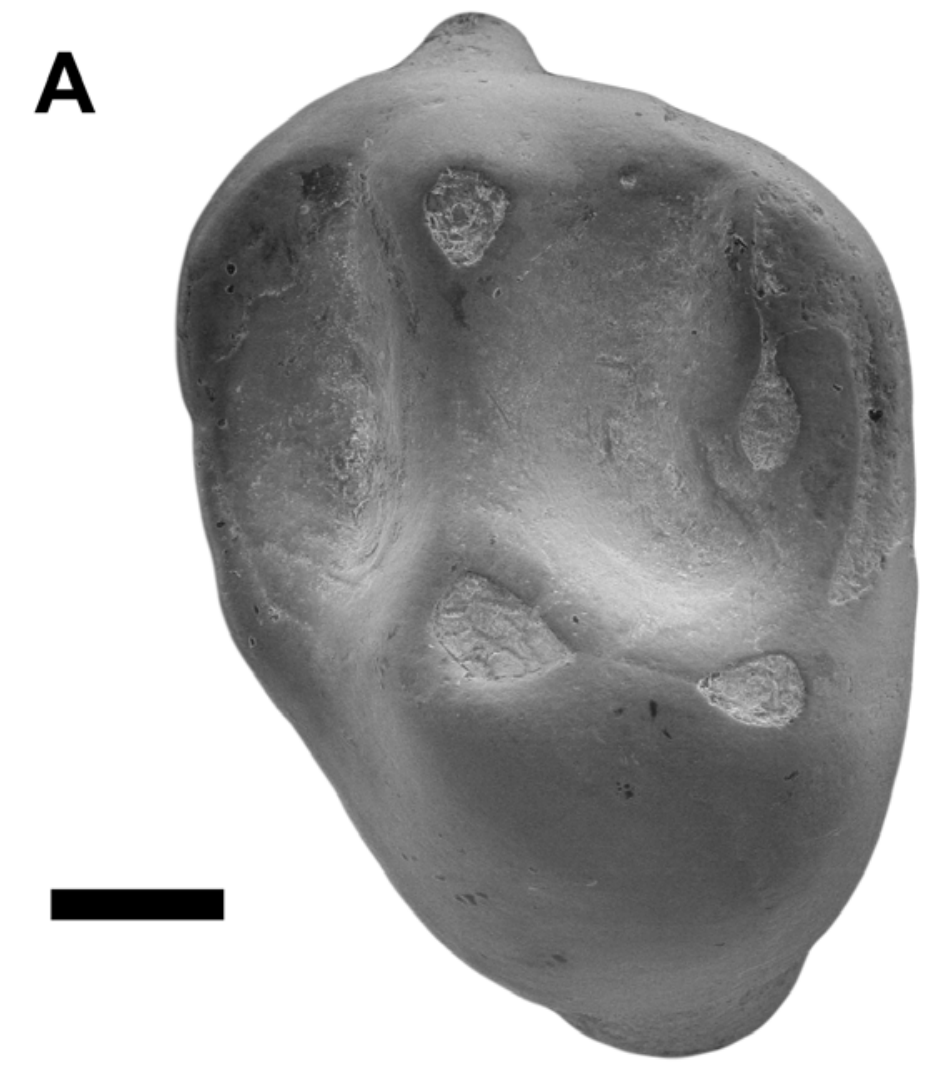

B

Fig. 12.5 